\title{
LAMP1 wt Allele
}

National Cancer Institute

\section{Source}

National Cancer Institute. LAMP1 wt Allele. NCI Thesaurus. Code C104628.

Human LAMP1 wild-type allele is located in the vicinity of $13 q 34$ and is approximately 27 $\mathrm{kb}$ in length. This allele, which encodes lysosome-associated membrane glycoprotein 1 protein, plays a role in selectin-mediated cell adhesion and may play a role in tumor cell metastasis. 